\title{
Management of stem borer (Chilo partellus Swinhoe) in maize using conventional pesticides in Chitwan, Nepal
}

\author{
Saraswati Neupane*, Ghanashyam Bhandari, \\ Sheela Devi Sharma, Surendra Yadav and Subash Subedi \\ Nepal Agricultural Research Council, \\ National Maize Research Program, Rampur, Chitwan, Nepal \\ *Corresponding author email: sarusanu2017@gmail.com
}

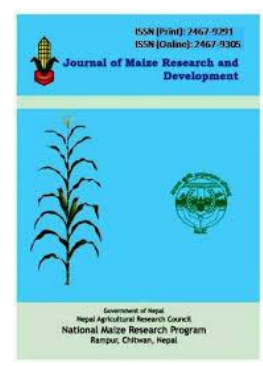

Received: September 2016; Revised: October 2016; Accepted: November 2016

\begin{abstract}
The stem borer (Chilo partellus Swinhoe) is one of the most destructive pests of maize crop. Research experimentations were carried out on maize to control stem borer using conventional pesticides under field condition during summer season of two consecutive years from 2015 to 2016 at Rampur, Chitwan. All used pesticides had significant effect $(\mathrm{P} \leq 0.05)$ on percent damage and crop yield over control. In 2015, the lower percent damage (5.3\%) with higher crop yield (4.52 $\mathrm{t}$ $\left.\mathrm{ha}^{-1}\right)$ and lowest insect score (1.00) was observed in plot sprayed with spinosad $45 \%$ EC at 0.5 $\mathrm{ml} \mathrm{L}^{-1}$ of water followed by plot treated with chloropyriphos $50 \%$ EC+cypermethrin $5 \% \mathrm{EC}$ @ $1.5 \mathrm{ml} \mathrm{L}^{-1}$ of water with percent damage of $6.60 \%$, crop yield $\left(4.23 \mathrm{t} \mathrm{ha}^{-1}\right)$ and insect score of 1.60. Almost similar trend of insect incidence along with damage percentage and yield data were observed in 2016. The higher percent damage control (79.06\%) was observed at the plot sprayed after spinosad $45 \% \mathrm{EC}$ at $0.5 \mathrm{ml} \mathrm{L}$ of water with higher crop yield $\left(4.58 \mathrm{t} \mathrm{ha}^{-1}\right)$ and lowest insect score (1.00) followed by the plot treated with imidacloprid $17.8 \% @ 0.5 \mathrm{ml} \mathrm{L}^{-1}$ of water with percent damage control of $73.10 \%$, crop yield $(3.38 \mathrm{t} / \mathrm{ha})$ and insect sore 1.50 . The highest percent damage $(20.63 \%)$ was observed in the control plot with lower yield $\left(0.95 \mathrm{t} \mathrm{ha}^{-1}\right)$ and highest insect score (6.00). Over the years, spinosad $45 \% \mathrm{EC}$ at $0.5 \mathrm{ml} \mathrm{L}^{-1}$ of water was effective bio-pesticide to control maize stem borer damage and also increase the yield.
\end{abstract}

Keywords: Maize, pesticide, stem borer

Correct citation: Neupane, S., Bhandari, G., Sharma, S., Yadav, S., \& Subedi, S. (2016). Management of stem borer (Chilo partellus Swinhoe) in maize using conventional pesticides. Journal of Maize Research and Development, 2(1), 13-19, doi: http://dx.doi.org/10.3126/jmrd.v2i1.16211 


\section{INTRODUCTION}

Maize stem borer (Chilo partellus Swinhoe) has been implicated as major insect pest to maize production throughout the country (Neupane, 1986). In severe cases, dead hearts are formed and such plants do not bear the ears. The loss caused by them has not been calculate accurately. However, some workers mentioned that the maize borer reported to cause a yield loss of 20-87\% (Mathur, 1994). Sometimes yield loss has measured up to 83\% (Chaterji et. al., 1969). With the introduction of new high yielding varieties/hybrids and advancement in farming technologies, the cropping pattern has changed. As a result of this, maize is grown now round the year i.e. rainy, winter and spring season. This has added new dimensions to the pestilence front. Insects hitherto have become problematic pests. Low productivity (National average 2.2 ton/ha) of maize in Nepal is attributed to many reasons. The one reason of low production is the attack of various insect pests. They attack maize plants from seeds sown in the field to maturity and feed on all parts of the plants (Gyawali, 1978; Shivakoti \& KC, 1978). Maize stem borer damage decreases the yield and lower grain quality (Pingali, 2001; James, 2003). Furthermore, non judicious use of wide spectrum insecticides during last few decades have resulted various problems. Haphazard uses of chemicals are not eco-friendly in the present context. Although, maize stem borer had major impact on yield losses, however scanty works related to pest management have been carried out against this pest in Nepal. So the present experiment has been attempted on maize to control stem borer using conventional pesticides under field condition.

\section{MATERIALS AND METHODS}

The experimentation was conducted at the research farm of National Maize Research Program, Rampur, Chitwan, Nepal during summer seasons of 2015-2016. The latitude, longitude and altitude of the experimental site are $27^{\circ} 40^{\prime} \mathrm{N}, 84^{0} 19^{\prime} \mathrm{E}$, and 228 masl respectively. Series of field experiments with 8 treatments (fipronil 0.3Gr @3-4 g per whorl, spinosad 45\% EC@0.5 ml $\mathrm{L}^{-1}$ of water, chloropyrifos 10\% EC @ $1.5 \mathrm{ml} \mathrm{L}^{-1}$ of water, Margosom @ $3 \mathrm{ml} \mathrm{L}^{-1}$ of water, chlorophyriphos 20\%EC (Darshan)@ $1.5 \mathrm{ml} \mathrm{L}^{-1}$ of water, chloropyriphos $50 \% \mathrm{EC}+$ cypermethrin $5 \% \mathrm{EC}$ (Super-D) @ $1.5 \mathrm{ml} \mathrm{L}^{-1}$ of water, imidachloprid 17.8\% (Confidor 200SL) @ $0.5 \mathrm{ml} \mathrm{L}^{-1}$ of water and control) were evaluated against maize stem borer. The experiments were laid in RCB design with three replications. The pipeline hybrid maize genotype RML-95/RML-96 was seeded on the first week of April (April 5, 2015) during first year of experimentation while next year, a released variety Rampur hybrid-2 was seeded on the third week of February (February 19,2016 ) in a unit plot size of 6 rows of $5 \mathrm{~m}$ long with the spacing of $60 \times 20 \mathrm{~cm}$ between row to row and plant to plant.

After a completion of sowing, the experiment was kept under constant supervision to an entire crop cycle. Agronomic practices were followed as recommended. Each experimental unit was fertilized with a recommended dose of 150:60:40 (N: P: K) $\mathrm{kg} \mathrm{ha}^{-1}$. Granular insecticides were applied at knee high stage in plant whorl where as liquid form of insecticides applied as foliar first at 15 days after emergence and second before tasseling stage. Insect data was recorded on the basis of 1-9 scoring scale as described by CIMMYT, Mexico (Tefera et al., 2011). 
Journal of Maize Research and Development (2016) 2 (1): 13-19

ISSN: 2467-9291 (Print), 2467-9305 (Online)

DOI: http://dx.doi.org/10.3126/jmrd.v2i1.16211

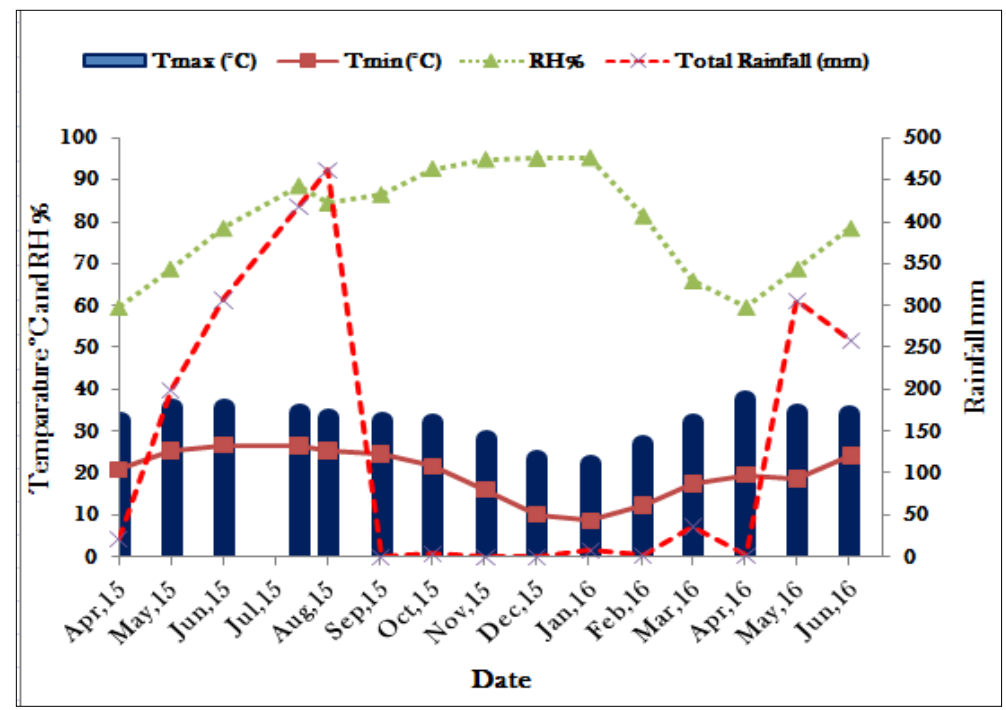

Figure 1. Meteorological data during experimental period (2015-2016) at Rampur, Chitwan Nepal.

Data on damage percentage at knee height and tasseling stage and yield (ton/hectare) were recorded. Yield increase over the control was calculated. The temperature, relative humidity and rainfall were measured during experiment period (Figure 1). All data were analyzed statistically using MSTAT-C and MS-Excel. Analysis of variance was done.

\section{RESULTS AND DISCUSSION}

\section{Efficacy of pesticides against maize stem borer}

All used conventional pesticides had significant effect $(\mathrm{P} \leq 0.05)$ on percent damage and crop yield over control. In 2015, the lower percent damage (5.30\%) with higher crop yield (4.52 t/ha) and lowest insect score (1.00) was observed in plot sprayed with spinosad $45 \%$ EC at 0.5 $\mathrm{ml} \mathrm{L}^{-1}$ of water followed by plot treated with chloropyriphos $50 \% \mathrm{EC}+$ cypermethrin $5 \% \mathrm{EC} @ 1.5$ $\mathrm{ml} \mathrm{L}^{-1}$ of water with percent damage of $6.60 \%$, crop yield $\left(4.23 \mathrm{t} \mathrm{ha}^{-1}\right)$ and insect score of 1.60 (Table 1).

Table 1. Effect of pesticides on damage percentage of stem borer and grain yield increase in maize at Rampur, Chitwan during 2015.

\begin{tabular}{|c|c|c|c|c|c|}
\hline Treatments & $\begin{array}{l}\text { IS } \\
\text { (0-9 scale) }\end{array}$ & \%DAS & $\% \mathrm{DC}$ & $\begin{array}{l}\text { GY } \\
\left(\mathbf{t ~ h a}^{-1}\right)\end{array}$ & YI (\%) \\
\hline 1. fipronil 0.3Gr@3-4 g/whorl & 2.00 & 11.00 & 36.05 & 4.01 & 35.02 \\
\hline 2. spinosad $45 \%$ EC@ $0.5 \mathrm{ml} / 1$ of water & 1.00 & 5.30 & 69.19 & 4.52 & 52.19 \\
\hline 3. furadon3 Gr@3-4g/whorl & 1.60 & 10.80 & 37.21 & 4.11 & 38.38 \\
\hline
\end{tabular}


Journal of Maize Research and Development (2016) 2 (1): 13-19

ISSN: 2467-9291 (Print), 2467-9305 (Online)

DOI: http://dx.doi.org/10.3126/jmrd.v2i1.16211

4. Margosom @ $3 \mathrm{ml} \mathrm{L}^{-1}$ of water

2.33

1.60

11.30

$34.30 \quad 3.93$

32.32

5.chlorophyriphos 20\%EC (Darshan)@ $1.5 \mathrm{ml} \mathrm{L}^{-1}$

of water

6. chloropyriphos $50 \% \mathrm{EC}+$ cypermethrin $5 \% \mathrm{EC}$

(Super-D) @ $1.5 \mathrm{ml} \mathrm{L}^{-1}$ of water

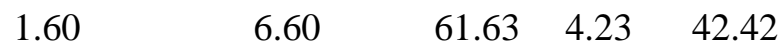

7. imidachloprid 17.8\% (Confidor 200SL) @ 0.5

2.00

7.60

$55.81 \quad 4.14$

39.39

$\mathrm{ml} \mathrm{L} \mathrm{L}^{-1}$ of water

8. Control (water spray)

$\begin{array}{lll}3.50 & 17.20 & 2.97\end{array}$

\begin{tabular}{|c|c|c|c|}
\hline Grand mean & 1.90 & 9.80 & 4.01 \\
\hline F test & $* *$ & $*$ & $* *$ \\
\hline LSD $_{0.05}$ & 0.67 & 5.22 & 0.31 \\
\hline CV\% & 19.50 & 30.20 & 4.42 \\
\hline
\end{tabular}

Note: ${ }^{\dagger}$ Means of 3 replication. IS- Insect Score, \%DAS- Percent Damage After Spray, \%DC- Percent Damage Control, GYGrain Yield, YI- Yield Increase, t/ha- ton per hectare, L- liter, EC- Emulsifiable concentration, ml- mililitre, g- gram, Gr- granule

\section{Relationship between insect damage control and yield increase in maize}

A linear positive correlation between insect damage control yield increase percentages was observed during 2015. The maize yield was found significantly highly positive correlation ( $\mathrm{r}$ $=0.89$ ) with the insect damage control percentage in maize stem borer management experiment through the application of conventional pesticides. The equation $\mathrm{Y}=0.412 \mathrm{X}+19.59$ and $\mathrm{R}^{2}=$ 0.80 gave the best fit (Figure 2). The estimated regression line indicated that the unit rise in the insect damage control percentage during experimentation period of first year (within 1-9 scale), there existed possibilities of yield increase by $0.41 \%$.

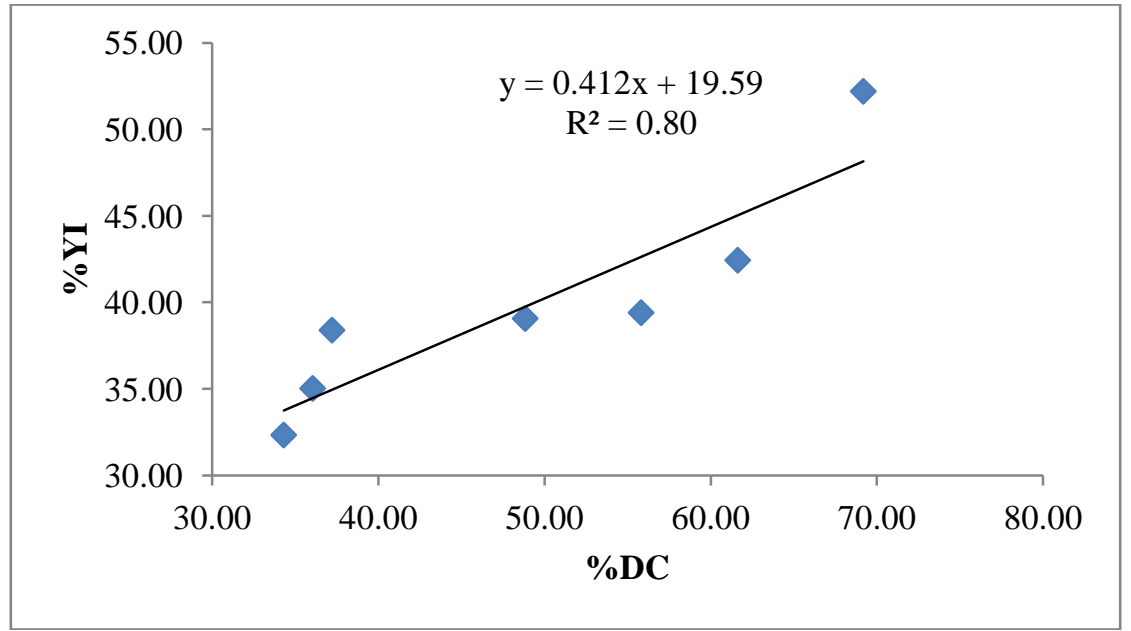

Figure 2: Relationship between percent damage control and percent yield increase in maize stem borer management experiment at Rampur, Chitwan during 2015.

Almost similar trend of insect incidence along with damage percentage and yield data were observed in 2016. 
Journal of Maize Research and Development (2016) 2 (1): 13-19

ISSN: 2467-9291 (Print), 2467-9305 (Online)

DOI: http://dx.doi.org/10.3126/jmrd.v2i1.16211

Table 2. Effect of pesticides on stem borer damage and grain yield in maize at Rampur, Chitwan during 2016.

\begin{tabular}{|c|c|c|c|c|c|c|}
\hline Treatments & $\begin{array}{l}\text { IS } \\
(0-9 \text { scale })\end{array}$ & \%DBS & \%DAS & $\% \mathrm{DC}$ & $\begin{array}{l}\text { GY } \\
\left(t \text { ha }^{-1}\right)\end{array}$ & YI \% \\
\hline 1. fipronil 0.3Gr @3-4 g/whorl & 4.67 & 9.85 & 7.10 & 65.58 & 2.08 & 118.95 \\
\hline $\begin{array}{l}\text { 2. spinosad } 45 \% \text { EC@0.5 } \mathrm{ml} \mathrm{L}^{-1} \text { of } \\
\text { water }\end{array}$ & 1.00 & 5.61 & 4.32 & 79.06 & 4.58 & 382.11 \\
\hline $\begin{array}{l}\text { 3. chloropyrifos } 10 \% \text { EC @ } 1.5 \mathrm{ml} \mathrm{L}^{-1} \\
\text { of water }\end{array}$ & 4.00 & 9.62 & 6.78 & 67.14 & 2.58 & 171.58 \\
\hline 4. Margosom @ $3 \mathrm{ml} \mathrm{L}^{-1}$ of water & 2.33 & 7.43 & 5.92 & 71.30 & 3.25 & 242.11 \\
\hline $\begin{array}{l}\text { 5.chlorophyriphos } 20 \% \mathrm{EC} \\
\text { (Darshan)@ } 1.5 \mathrm{ml} \mathrm{L}^{-1} \text { of water }\end{array}$ & 3.33 & 9.03 & 6.50 & 68.49 & 2.72 & 186.32 \\
\hline $\begin{array}{l}\text { 6.chloropyriphos50\%EC+cypermethrin } \\
5 \% \mathrm{EC} \text { (Super-D) @ } 1.5 \mathrm{ml} \mathrm{L}^{-1} \text { of } \\
\text { water }\end{array}$ & 3.17 & 8.56 & 6.22 & 69.85 & 2.95 & 210.53 \\
\hline $\begin{array}{l}\text { 7. imidachloprid } 17.8 \% \text { (Confidor } \\
200 \mathrm{SL}) @ 0.5 \mathrm{ml} \mathrm{L}^{-1} \text { of water }\end{array}$ & 1.50 & 8.30 & 5.55 & 73.10 & 3.38 & 255.79 \\
\hline 8. Control (water spray) & 6.00 & 9.19 & 20.63 & & 0.95 & \\
\hline Grand mean & 3.25 & 8.45 & 7.88 & & 2.81 & \\
\hline F test & $* *$ & $* *$ & $* *$ & & $* *$ & \\
\hline LSD $_{0.05}$ & 0.93 & 1.09 & 0.65 & & 0.28 & \\
\hline CV\% & 16.40 & 7.39 & 4.72 & & 5.67 & \\
\hline
\end{tabular}

Note: ${ }^{\dagger}$ Means of 3 replication. IS- Insect score, \%DBS- percent Damage Before Spray, \%DAS- Percent Damage After Spray, \%DC- Percent Damage Control, GY- Grain Yield, YI- Yield Increase, t/ha- ton per hectare, L- liter, EC- Emulsifiable concentration, ml- mililitre, g- gram, Gr- granule

The lower percent damage $(4.32 \%)$ was observed at the plot sprayed after spinosad $45 \%$ EC at $0.5 \mathrm{ml} \mathrm{L}^{-1}$ of water with higher crop yield $\left(4.58 \mathrm{t} \mathrm{ha}^{-1}\right)$ and lowest insect score (1.00) followed by the plot treated with imidacloprid $17.8 \% @ 0.5 \mathrm{ml} \mathrm{L}^{-1}$ of water with percent damage of $5.55 \%$, crop yield $\left(3.38 \mathrm{t} \mathrm{ha}^{-1}\right)$ and insect sore 1.50 . The highest percent damage $(20.63 \%)$ was observed in the control plot with lower yield (0.95 t/ha) and highest insect score (6.00) (Table 2).

\section{Relationship between insect damage and yield}

A linear negative correlation between yield and insect damage was observed during 2016. The maize yield was found significantly negative correlation $(r=-0.82)$ with the insect damage percentage in maize stem borer management experiment through the application of conventional pesticides. The equation $\mathrm{Y}=-0.164 \mathrm{X}+4.110$ and $\mathrm{R}^{2}=0.67$ gave the best fit (Figure 3 ). The estimated regression line indicated that the unit rise in the insect damage percentage during two years of experimentation (within 1-9 scale), there existed possibilities of yield reduction by 0.164 $\mathrm{t} \mathrm{ha}^{-1}$. Two year's results revealed that plot sprayed with biorational pesticide spinosad (Tracer $45 \%$ SC) @ $0.5 \mathrm{ml} \mathrm{L-1} \mathrm{of} \mathrm{water} \mathrm{showed} \mathrm{the} \mathrm{highest} \mathrm{efficacy} \mathrm{against} \mathrm{C.} \mathrm{partellus} \mathrm{with} \mathrm{higher}$ yield followed by imidacloprid @ $0.5 \mathrm{ml} \mathrm{L-1}$ of water. This finding is supported by Ahmed et al. (2002), who found that among the biopesticides, microbial toxin spinosad (Saccharopolyspora spinosa) was the most effective against C. partellus where pest infestation was reduced to $3.05 \%$ after first spray. 


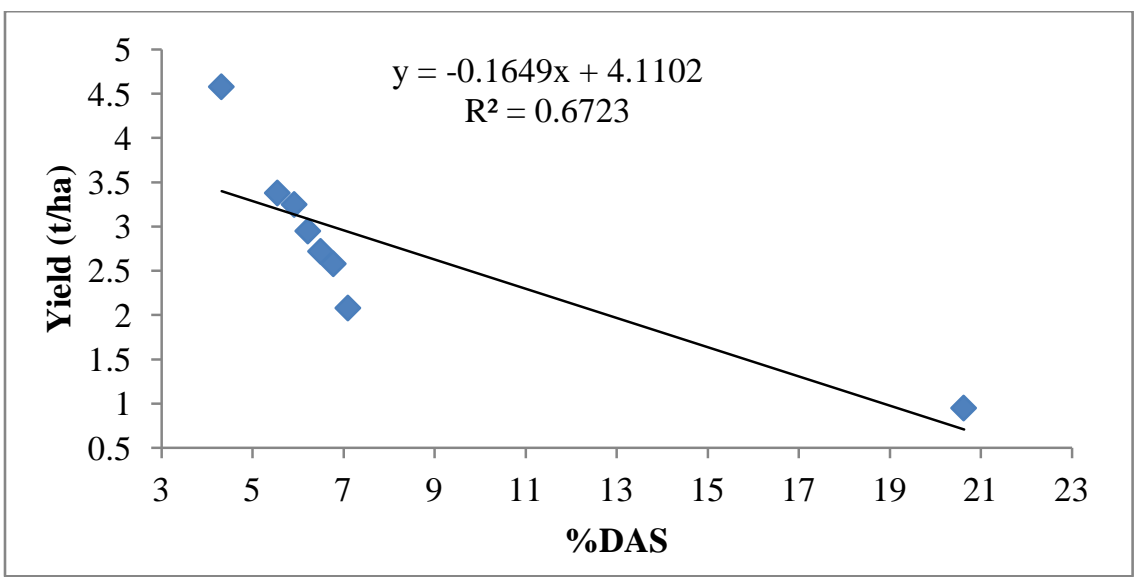

Figure 3. Relationship between insect damage \% after spray and crop yield in maize stem borer management experiment at Rampur, Chitwan during 2016.

The mode of action of spinosad insecticides is may be by a neural mechanism (Orr et al., 2009). The spinosyns and spinosad have a novel mode of action, primarily targeting binding sites on nicotinic acetylcholine receptors of the insect nervous system that is distinct from those at which other insecticides have their activity. Spinosoid binding leads to disruption of acetylcholine neurotransmission (Qiao et al., 2007). Spinosad also has secondary effects as an amino-butyric acid (GABA) neurotransmitter agonist. It kills insects by hyper-excitation of the insect nervous system (Qiao et al., 2007). Spinosad so far has proven not to cause crossresistance to any other known insecticide (Sparks et al., 2001). Among chemicals, imidacloprid provided the best control of maize stem borer with high yield from the treated plots. The present findings can also be compared with those of Mashwani et al. (2011), who reported that imidacloprid was the most effective insecticide in suppressing the $C$. partellus by $97.3 \%$. The finding of this study is also in close agreement with the findings of Sharma and Gautam (2010) who reported that in control plots, maize yield was less by $27.9 \%$ due to infestation of maize stem borer as compared to pesticide applied plots. Several control approaches such as biological, cultural and judicious use of chemicals are equally important against maize stem borer (Sharma \& Gautam, 2010).

\section{CONCLUSION}

Over the years, the plot sprayed twice with spinosad $45 \% \mathrm{EC}$ at $0.5 \mathrm{ml} \mathrm{L}^{-1}$ of water during foliar first at 15 days after emergence and second before tasseling stage was found effective bio-pesticide to control maize stem borer damage and also increase the yield.

\section{ACKNOWLEDGEMENTS}

The authors are grateful to the NMRP Coordinator and NARC for financial support in this study. The research team of NMRP, Rampur is gratefully acknowledged for trial 
Journal of Maize Research and Development (2016) 2 (1): 13-19

ISSN: 2467-9291 (Print), 2467-9305 (Online)

DOI: http://dx.doi.org/10.3126/jmrd.v2i1.16211

management and data recording. All peoples who provided valuable opinions and ideas on this manuscript are also appreciated.

\section{REFERENCES}

Ahmad, S., Mushtaq, A., \& Rauf, I. (2002). Field efficacy of some bio-insecticides against maize and jowar stem borer, Chilo partellus (Lepidoptera: Pyralidae). International Journal of Agriculture \& Biology, 4(3), 332-334.

Chatterji, S.M., Young, W.R., Sharma G.C., Sayi, I.V., Chall, B.S., Khare, B.P., Rathor, Y.S., Panwar, V.P.S., \& Siddiqui, K.H. (1969). Estimate of loss in maize due to insect of maize with special reference to borer. Indian Journal of Entomology, 31, 109-115.

Gyawali, B.K. (1978). Studies on field biology on maize borer. The 4th National Maize Development Workshop (Jan 9-19, 1978) held at Rampur, Chitwan Nepal.

James, C. (2003). Global Review of Commercialized Transgenic Crops: 2002 Feature: Bt Maize. ISAAA. Brief No. 29. ISAAA: Ithaca, New York USA.

Mashwani, A.M., Ullah, F., Sattar, S., Ahmand, S., \& Khan, M.A. (2011). Efficacy of different insecticides against maize stem borer, Chilo partellus swinhoe (Lepidoptera: Pyralidae) at Peshawar and Swat valleys of Khyber Pakhutunkhwa, Pakistan. Sarhad Journal of Agriculture, 27(3), 459-465.

Mathur, L.M.L. (1994). Advances in insect pest management in Maize. In: G.S. Dhaliwal and Ramesh (eds.), Trends of agriculture insect pest management, Common wealth publisher, New Delhi, India, pp.113-160.

Neupane, F.P. (1986). Temperature-developmental relationship of maize borer, Chilo partellus (Lepidopter: Pyralidae) in Nepal. Nepalese Journal of Agricultural Science 17, 23-35.

Orr, N., Andrew, J., Shaffner, K.R., \& Gary. D.C. (2009). Novel mode of action of spinosad: Receptor binding studies demonstrating lack of interaction with known insecticidal target sites. Pesticide Biochemistry and Physiology, 95, 1-5.

Pingali, P.I. (2001). CIMMYT. 1999-2000. World Maize Facts and Trends, Meeting World Maize Need: Technological Opportunities and Priorities for the Public Sector. CIMMYT, Mexico. D.F. 57p.

Qiao, M., Daniel, E., Snyder, J.M., Alan, G.Z., Sonya, J.G., Larry, R.C., Robyn, L.S., \& Davide, R.Y. (2007). Preliminary Studies on the effectiveness of the novel pulicide, spinosad, for the treatment and control of fleas on dogs. Veterinary Parasitology, 1, 345-351.

Saxena, K.C., \& Shrivastav, R.C. (1997). Insect pest of maize crop. In: Entomology, at a glance, New Delhi, India. 219p.

Sharma, P.N., \& Gautam, P. (2010). Assessment of yield loss in maize due to attack by the maize borer, Chilo partellus (Swinhoe). Nepal Journal of Science and Technology, 11, 25-30.

Sparks, T., Gary, D.C., \& Gregory, D. (2001). Natural products as insecticides: the biology, biochemistry and quantitative structure-activity relationships of spinosyns and spinosoids". Pest Management Science, 57, 896-899.

Tefera T., Mugo, S., Tende, R., \& Likhayo, P. (2011). Methods of Screening Maize for Resistance to Stem Borers and Post-harvest Insect Pests. CIMMYT. Nairobi, Kenya. pp. 1-30. 